\title{
New method of preoperative selection of patients with gastro-oesophageal reflux disease
}

\section{Nowa metoda przedoperacyjnej selekcji pacjentów z chorobą refluksową przełyku}

\author{
Siarhei Pankoํㅡㄹ Henadzi Zhurbenka², Aliaksandr Karpitski², Rostislav Boufalik², Dzianis Vakulich², \\ Andrei Shestiuk ${ }^{3}$, Aliaksandr Ihnatsiuk²
}

${ }^{1}$ Department of Emergency Medicine, Faculty of Health Sciences, Jan Kochanowski University of Humanities and Sciences, Kielce, Poland

Head of the Department: Siarhei Panko

2Department of of Thoracic Surgery, Brest Regional Hospital, Brest, Belarus

Head of the Department: Rostislav Boufalik

${ }^{3}$ Department of Anatomy and Physiology, Brest State University, Brest, Belarus

Head of the Department: Siarhei Panko

Key words: hiatal hernia, gastro-oesophageal reflux disease, computed tomography, Sengstaken-Blakemore tube.

Słowa kluczowe: przepuklina rozworu przełykowego, choroba refluksowa przełyku, tomografia komputerowa, sonda Sengstaken-Blakemore.

\begin{abstract}
Introduction: The identification of sliding hiatal hernia ( $\mathrm{SHH}$ ) less than $3 \mathrm{~cm}$ in size using barium swallow fluoroscopy (BSF) and oesophagogastroduodenoscopy (OGD) was recently noted as a non-reliable method, allowing for approximately $2 \mathrm{~cm}$ of inherent error in its size estimate.

Aim of the research: We aimed to develop a reliable method, which could be used for preoperative visualisation and accurate anatomic depiction of any hiatal hernia and anatomical abnormalities in patients with incomplete gastro-oesophageal reflux disease (GORD) symptom remission after appropriate medical therapy.

Material and methods: Within the period 2015-2017, 29 GORD patients (15 women, mean age 51 years) with incomplete symptom resolution on acid inhibition and equivocal findings as for SHH after endoscopy and/or BSF, were evaluated before laparoscopic anti-reflux surgery (LARS) using a computed tomography scan with a Sengstaken-Blakemore tube (CTSBT) provocation probe to confirm hernia existence. We calculated the sensitivity of each of these diagnostic tests.

Results: SHH was diagnosed in 21 patients by OGD and/or BSF, but during the surgery this diagnosis was confirmed in 18 patients. The sensitivity was found to be significantly higher in CTSBT modality, comparing with each of the other diagnostic tests and even higher than in OGD and BSF together.

Conclusions: CTSBT has been verified as the most efficient method to confirm or rule out SHH diagnosis or other anatomical abnormalities, which could be used to provide a surgeon with detailed information while making a decision about the advisability of LARS.
\end{abstract}

\section{Streszczenie}

Wprowadzenie: Rozpoznawanie wślizgowej przepukliny rozworu przełykowego (SHH) o rozmiarze mniejszym niż $3 \mathrm{~cm}$ z zastosowaniem fluoroskopii z barytem (BSF) i ezofagoduodendoskopii (OGD) zostało ostatnio uznane za mało wiarygodną metodę, pozwalająca na ok. $2 \mathrm{~cm}$ błędu w oszacowaniu jej wielkości.

Cel pracy: Opracowanie metody, która może być wykorzystana do przedoperacyjnej wizualizacji i dokładnego anatomicznego obrazowania SHH i innych nieprawidłowości anatomicznych u pacjentów z chorobą refluksową przełyku (GORD).

Materiał i metody: W latach 2015-2017 u 29 pacjentów (15 kobiet, średni wiek: 51 lat) z niepełną remisją GORD po odpowiedniej terapii lekowej, u których wcześniej zdiagnozowano GORD i podejrzewano SHH na podstawie wyników endoskopii i/lub BSF, wykonano tomografię komputerową z zastosowaniem sondy Sengstaken-Blakemore (CTSBT) przed laparoskopową operacją antyrefluksową (LARS) w celu potwierdzenia obecności przepukliny. Różnicę czułości testów diagnostycznych obliczono za pomocą testu McNemar's Chi-square.

Wyniki: Przepuklinę rozpoznano u 21 pacjentów za pomoca OGD i/lub BSF, chociaż w trakcie operacji rozpoznanie potwierdzono tylko u 18 pacjentów. Czułość diagnostyczna była znacznie wyższa w zakresie modalności CTSBT, gdy porównano ją z każdym z pozostałych testów diagnostycznych, a nawet wyższa niż w OGD i BSF razem. 
Wnioski: CTSBT została uznana za skuteczna metoda potwierdzania lub wykluczania SHH lub innych nieprawidłowości anatomicznych i może być wykorzystana w celu dostarczenia chirurgowi szczegółowych informacji podczas podejmowania decyzji o konieczności LARS.

\section{Introduction}

Patients with sliding hiatal hernia (SHH) demonstrate the existence of all gastroesophageal reflux disease (GORD) pathognomonic symptoms, such as bloating, early satiation, vomiting, dysphagia, odynophagia, hoarseness, and dyspnoea; however, it may not be possible to determine the presence of SHH based solely on the patient's history. The hiatal hernia in patients with GORD excessively stimulates existing gastroesophageal reflux, playing a permissive role in early progress of the disease or its exacerbation. Sliding hiatal hernia can be diagnosed based on the results of endoscopy, upper gastrointestinal multi-positional fluoroscopy, and high-resolution oesophageal manometry [1].

Endoscopic evidence of reflux oesophagitis cannot be found in most patients with hiatal hernia, but instead a concomitant hiatal hernia can be found in about $90 \%$ of patients with reflux disease when appropriate radiographic techniques are used [2].

The definition of $\mathrm{SHH}$ is based on the assessment and measurement of the anatomic relationship of the distal oesophagus, hiatus, and stomach. The fact that these relationships are not static and the presence of high mobility of the oesophagogastric junction (OGJ), makes it difficult to standardise the diagnostic approach [3-5]. Any chosen method of measurement can itself change the result of the assessment; therefore, the data received by oesophagogastroduodenoscopy (OGD) might be different from barium swallow fluoroscopy (BSF) results or similarly to results of intra-oesophageal manometry [6]. Reliable BSF evaluation for hiatal hernia requires visualisation of the squamous-columnar mucosal junction ring (i.e. $Z$ line or Schatzki ring), a level of the diaphragmatic hiatus that is estimated indirectly as a "pinched-cock" effect, a notch from the gastric sling fibres, oral level of the gastric area of the stomach, and termination site of primary oesophageal peristalsis [7].

Conventionally, a distinction between normal and hiatus hernia is more than $2 \mathrm{~cm}$ separation space measured in between the $\mathrm{Z}$ line ring and the diaphragmatic hiatus "pinched-cock". Nonetheless, the $\mathrm{Z}$ line ring can be visible in only approximately $15 \%$ of individuals and a measured hernia size will reflect about $1 \mathrm{~cm}$ difference, depending on whether it was taken early in the peristaltic sequence or near its termination [8].

Measurement of sliding hernias with less than $3 \mathrm{~cm}$ in size with BSF is recognised as a non-reliable measurement method, due to the magnitude of the size estimation with an inherent $2 \mathrm{~cm}$ error. Moreover, the miscalculation frequency and errors in identification and measurement of sliding hiatus hernia size dramatically increase with the addition of abdominal compression during barium swallow imaging. Due to this inherent uncertainty in the radiographic criteria for defining $\mathrm{SHH}$, estimates of prevalence may vary enormously, from $10 \%$ up to $80 \%$ [9].

The retroflexed imaging endoscopy has a similar inherent $2 \mathrm{~cm}$ error of the size estimate, also preventing it from being a preferred method for identification of the hiatal hernias with size less than $3 \mathrm{~cm}$ [10].

\section{Aim of the research}

Taking into consideration the available data, our group aimed to develop and introduce the most reliable method, which could easily be performed in the clinic and used by surgeons for preoperative visualisation and accurate anatomic depiction in GORD patients with any sliding hiatal hernia, including those smaller than $2 \mathrm{~cm}$ with an intra-abdominally reducible OGJ in the upright position.

\section{Material and methods}

In period from March 2015 to October 2017, 29 patients (15 women, mean age $51 \pm 15$ years, age range 17 to 72 years) with incomplete GORD symptom remission despite appropriate medical therapy, which was confirmed by endoscopy and/or 24-hour pHmetry, and who had ambiguous findings for $\mathrm{SHH}$ after endoscopy and/or barium swallow fluoroscopy, were evaluated before undergoing laparoscopic antireflux surgery (LARS), using computed tomography (CT) scan along with Sengstaken-Blakemore tube test, to confirm or exclude the presence of the hernia and make the decision about advisability of surgical treatment. The study was approved by the Hospital Ethical Committee, and written, informed consent was obtained from each patient.

\section{Computed tomography scan modality (CTSBT)}

After the Sengstaken-Blakemore tube was inserted per orally and the gastric balloon was positioned in the stomach, the balloon was inflated with $60 \mathrm{ml}$ of air, so that its diameter was $51-55 \mathrm{~mm}$, according to the CT-scan data. The tube was then pulled gently up until resistance against the diaphragm occured and was felt by the patient. The tube was then fixed between the patient's front incisors. The oesophageal balloon was also inflated with $40 \mathrm{ml}$ of air, so its diameter did not exceed $20 \mathrm{~mm}$ and the lower oesophageal sphincter (LOS) contraction could cause compression of the balloon, visible on the CT scan (ring A, Figures 1 A, 2 A, 3 A). After both balloons were cor- 
A

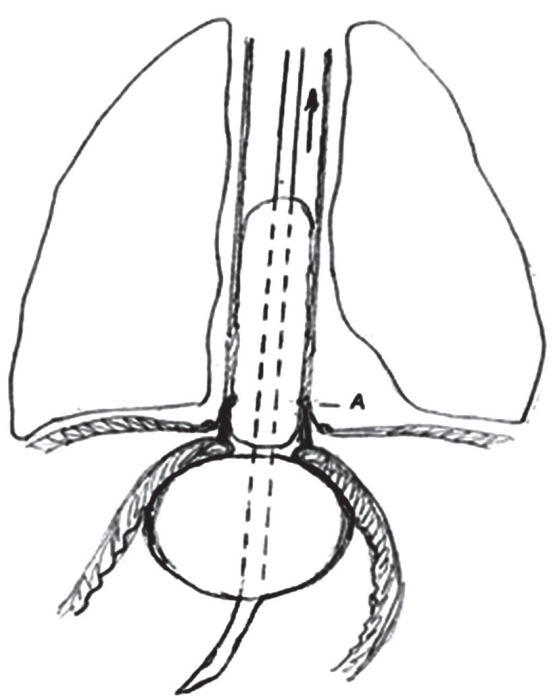

$A$ - ring A - upper border of the LOS.

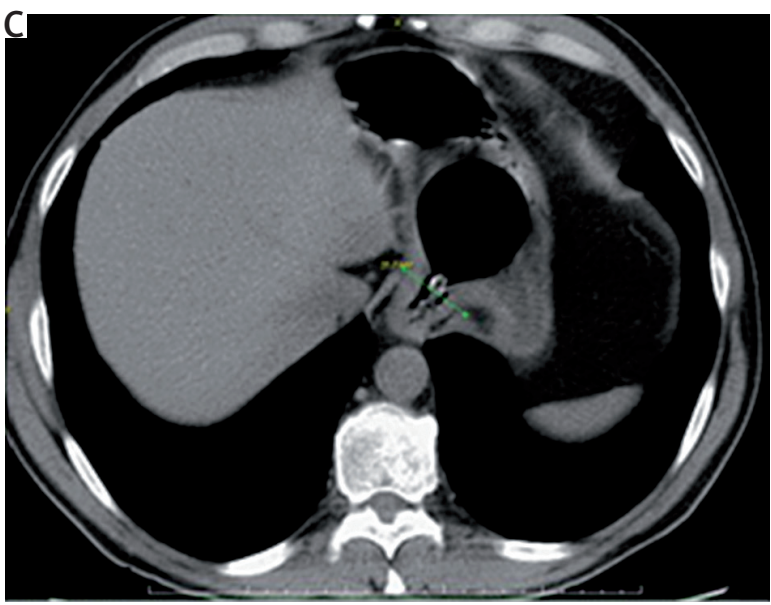

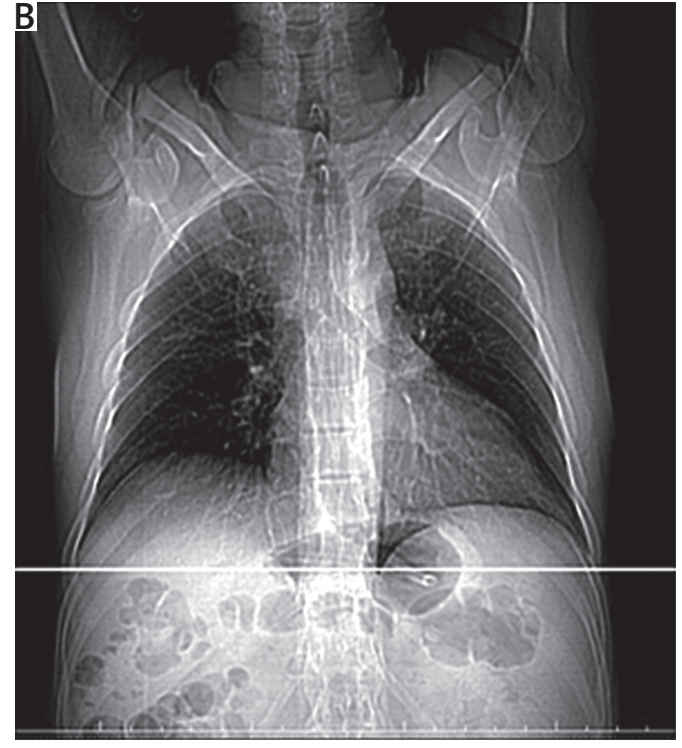

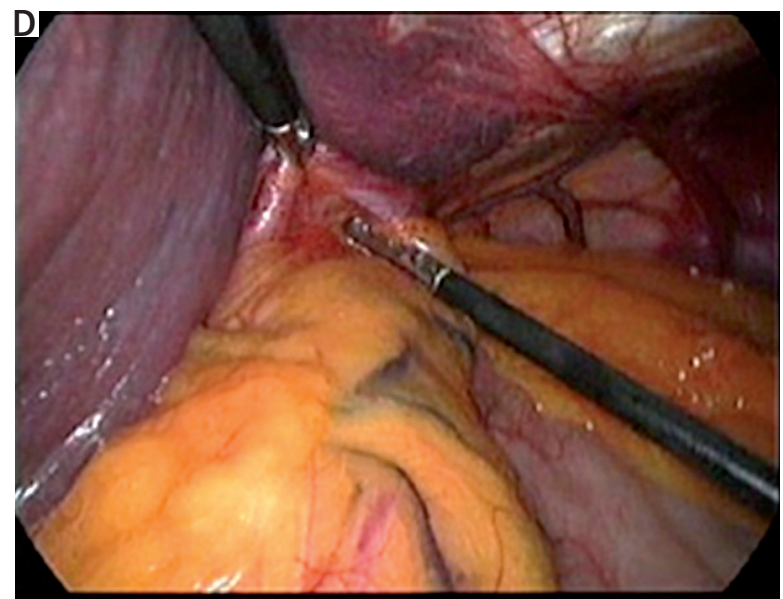

Figure 1. The scheme of Sengstaken-Blakemore tube provocation of the sliding hiatal hernia (A) and computed tomography scan (B, C) and laparoscopic (D) images of a patient without hiatal hernia (group I)

rectly positioned, a standard examination of the patient in the supine position was performed within one breath-and-hold cycle, following maximum inspiration. In both cases, with or without the hiatal hernia and the intra-abdominal oesophageal segment presence, the gastric balloon had to be fixed at the level of muscular elements of the crural diaphragm (CD) area after the $60-\mathrm{ml}$ inflation and cranial traction.

We assumed that visualisation of the inflated balloons might not only identify the presence of a sliding hiatus hernia and the upper margin of the lower oesophageal sphincter, but might also obtain information about the size of phrenic ampulla, oesophageal vestibule, and dehiscence of diaphragmatic crura in patients with GORD. All of the 29 GORD patients subsequently underwent LARS, and the presence of a hernia sac with contents within its gastric pouch was the laparoscopic criterion of a hiatal hernia.

\section{Statistical analysis}

The most indicative variables obtained by CTSBT modality and the sensitivity (\%) of each diagnostic test were calculated. Continuous data are reported as median and range. Mann-Whitney $U$ test was used to compare continuous variables between groups, Wilcoxon matched pairs test to compare variables within groups, and McNemar's chi-square test to compare sensitivity (\%) between diagnostic tests. A $p$-value $<0.05$ was considered significant.

\section{Results}

To describe the results of CTSBT scans we took under consideration the following parameters presented in Table 1 . In 5 cases (Figures 1 A, B) gastric balloon fixation was below $\mathrm{CD}$, but the majority of patients $(n=22)$ had fixation at the level of the CD 
A

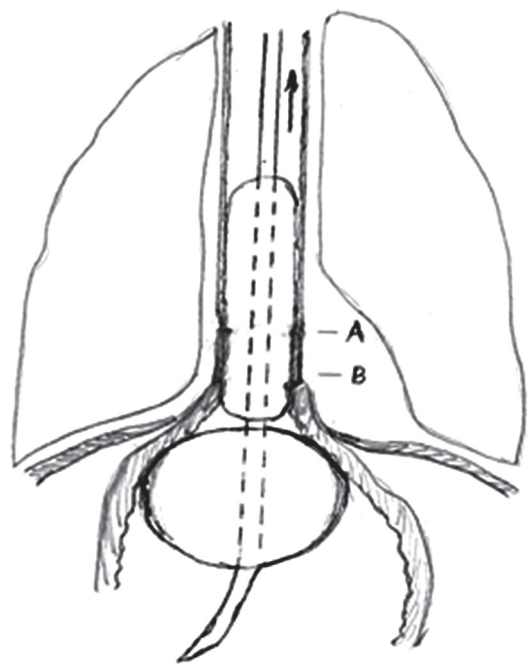

$A$ - ring $A$ - upper border of the LOS, B - ring B - lower border of the LOS-OGJ point.

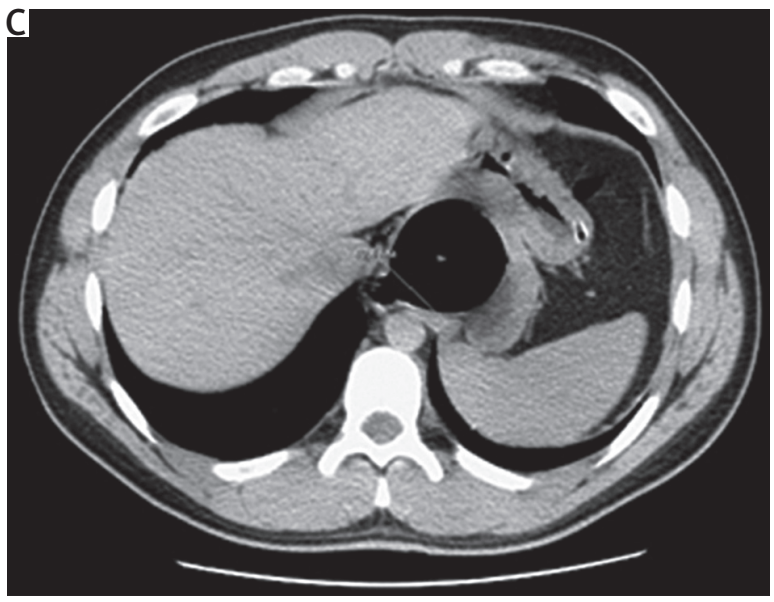

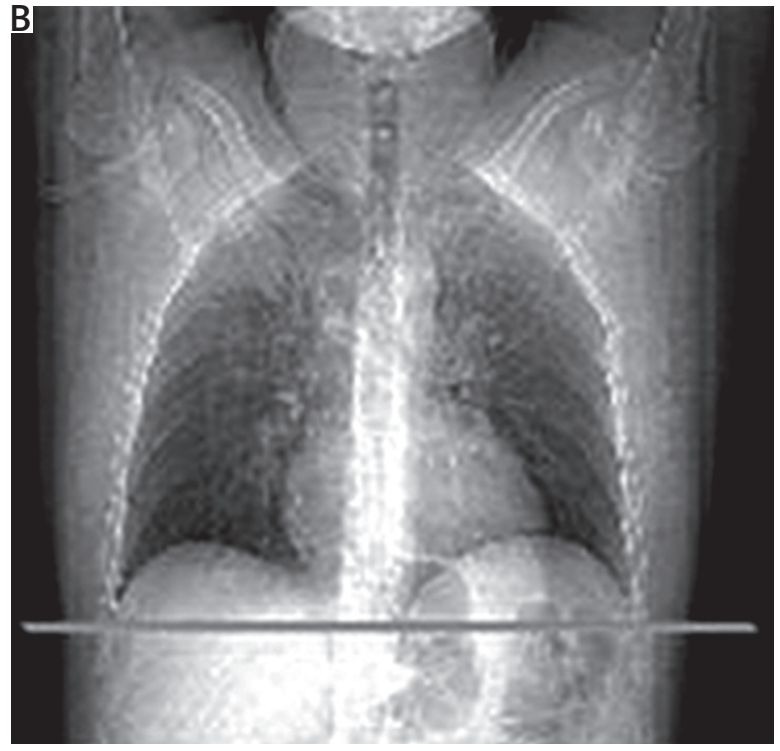

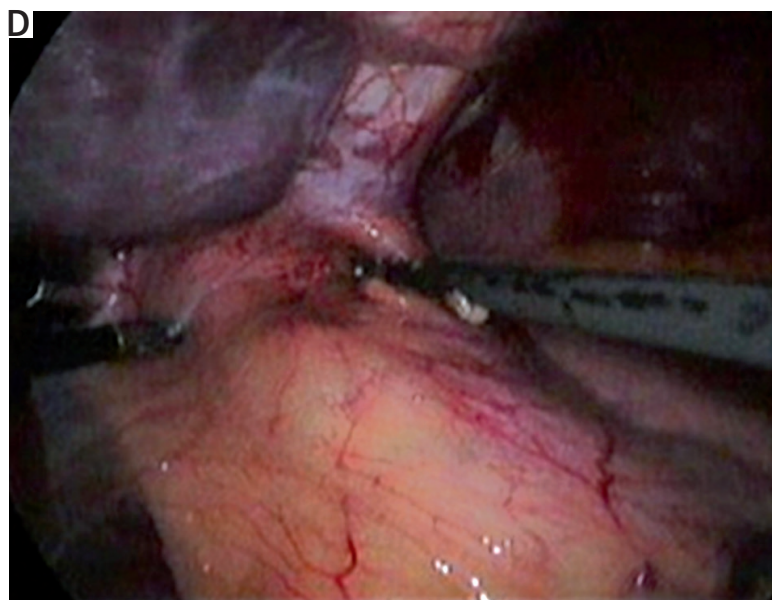

Figure 2. The scheme of Sengstaken-Blakemore tube provocation of the sliding hiatal hernia (A) and computed tomography scan (B, C) and laparoscopic (D) images of a patient with small reducing hiatal hernia (group II)

(Figures 2 A, B). In 2 patients the gastric balloon was fixed in the mediastinum above the CD due to dehiscence of diaphragmatic crura more than the balloon diameter during traction of SBT (Figures 3 A, B). These 2 patients were referred to a group with a diagnosis of non-reducing $\mathrm{SHH}$ (group III), and the 5 patients mentioned above with the balloon fixation under CD were referred to a group with no axial SHH (group I).

All the other 22 patients had clearly defined separation between the OGJ point and CD. However, in six cases no proven laparoscopic confirmation of the presence of a hernia (Figure 2 D) was found, which allows us to classify those patients as a new subgroup with small reducing SHH (group II).

In group III, the remaining 18 patients had a significantly greater $(46(26-60) \mathrm{mm} ; p<0.05)$ hernia size, (separation between the squamosal-columnar junction and the crural diaphragm), compared with group II (18.5 (8-29) mm), which indicated the presence of an axial hernia and, subsequently, was confirmed by laparoscopy (Figure $3 \mathrm{D}$ ). As for the first group, the absence of a hernia did not mean the absence of any other morphological abnormality findings.

Among those patients the maximum width of the hiatus (Figure $1 \mathrm{C}$ ) was greater $(23(17-32) \mathrm{mm})$ than the normal one described by other authors $(15 \mathrm{~mm})$ [11], although this estimate was significantly smaller than in the second (35 (25-49) mm; Figure 2 C) and third groups (33 (20-50) mm; Figure $3 \mathrm{C}$ ).

It can be clearly seen in Table 1 that the oesophagus-gastric gradient of the wall thickness is easily determined in all of these three groups and in the whole cohort by CTSBT modality $(2.0 \mathrm{~mm}$ against $4.8 \mathrm{~mm}$, $p<0.01$ ), which allows accurate determination of the location of the "OGJ point" (ring B Figure 2 A, Figure $3 \mathrm{~A}$ ) and to measure the distance between the 
A

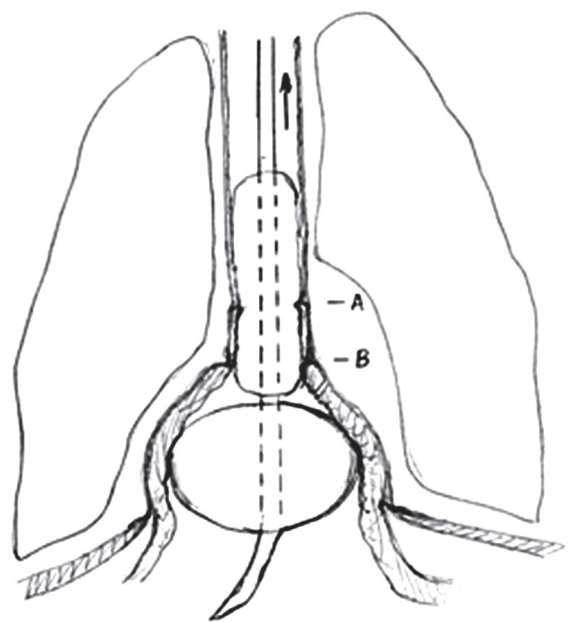

$A$ - ring $A$ - upper border of the LOS, B - ring B - lower border of the LOS - OGJ point.

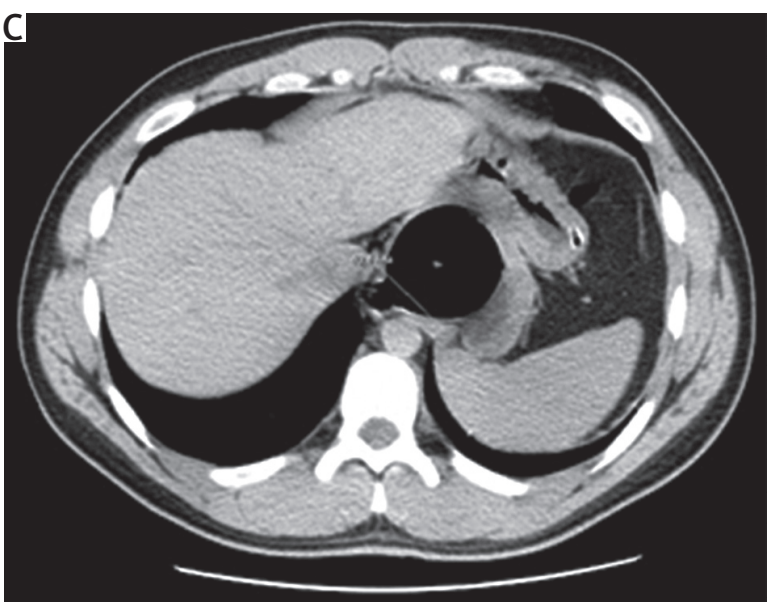

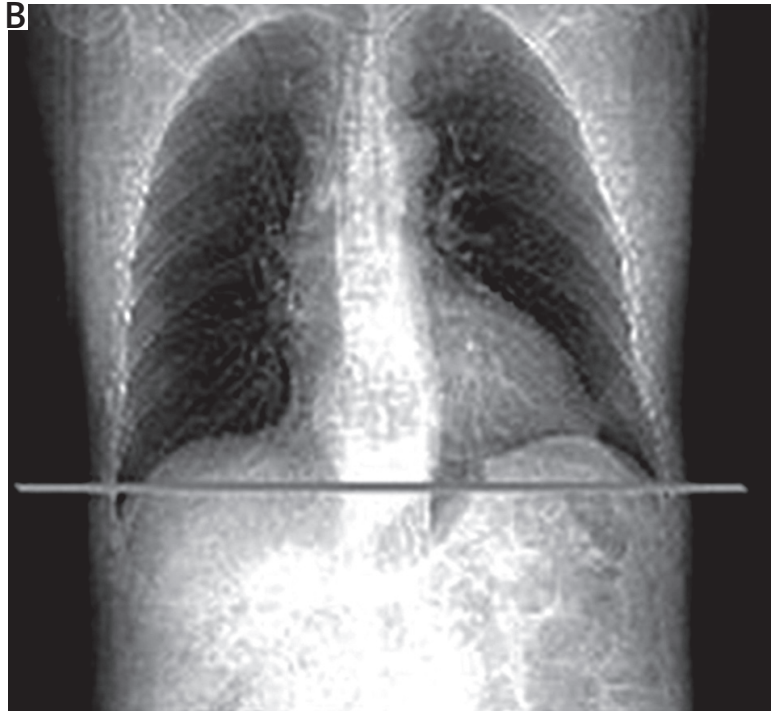

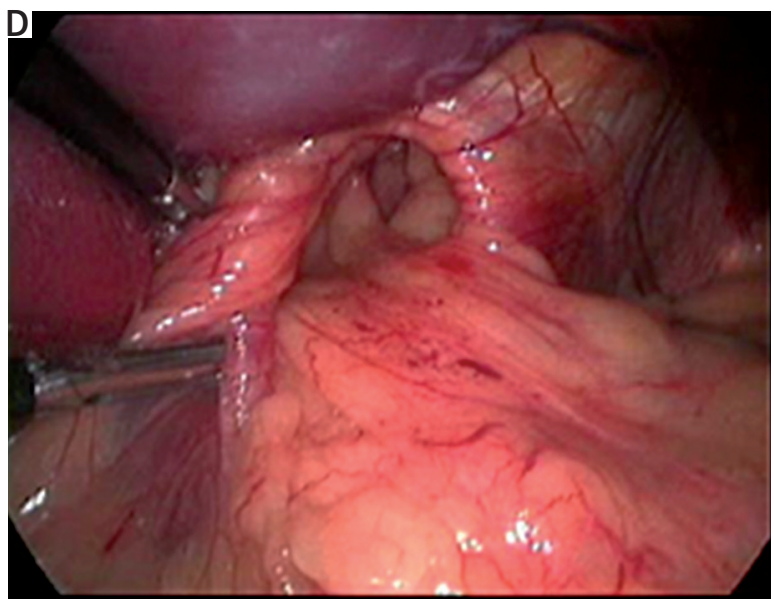

Figure 3. The scheme of Sengstaken-Blakemore tube provocation of the sliding hiatal hernia (A) and CT (B, C) and laparoscopic (D) images of a patient with non-reducing sliding hiatal hernia (group III)

"point" and the crural diaphragm. The median length of LOS in groups II and III (separation between A and B ring - "oesophageal vestibule") was $16.5 \mathrm{~mm}$ and $20 \mathrm{~mm}$, respectively, although a significant difference in this estimator was only noted between the third and the first group $(10 \mathrm{~mm})$

Even with minimally measurable separation between the lower oesophageal sphincter and the diaphragm on CT scan with Sengstaken-Blakemore tube provocation, confirmation of the presence of a sliding hiatal hernia was obtained. For example, one patient, who was diagnosed by endoscopy but not by fluoroscopy or surgery (with only "dimpling" anterior to the oesophagus), had separation of $8 \mathrm{~mm}$ size on CTSBT scan, phrenic ampulla length of $20 \mathrm{~mm}$, and hiatus width of $32.5 \mathrm{~mm}$. These findings gave enough reasons to refer him for group II (small reducing $\mathrm{SHH}$ ).
Become clear that this differentiation into groups is symbolic only, however, this limitation does not reduce importance and clinical relevance of the proposed method. The decision to perform surgery in these patients with incomplete symptom remission after appropriate medical therapy was largely based on the presence of substantial anatomical abnormalities in the OGJ region, which could be corrected by laparoscopic anti-reflux surgery.

SHH hernia was determined in 19 patients by endoscopy and in 13 cases fluoroscopically, and the total number of individuals diagnosed by OGD and/or BSF was 21.

During surgery, the diagnosis of SHH "with mediastinal hernia sac and gastric pouch within it" was confirmed in the 18 patients, and initially it was taken as the gold standard for the validation of the other preoperative hiatal hernia diagnostic tests. However, 
Table 1. Basic variables (median, range) of computed tomography scan along with Sengstaken-Blakemore tube test

\begin{tabular}{|c|c|c|c|c|c|}
\hline Group & SHH length [mm] & MHW [mm] & LOS length [mm] & OesoW [mm] & CardW [mm] \\
\hline $\begin{array}{l}\text { I }(n=5) \\
\text { Dehiscence } \\
\text { of diaphragmatic crura }\end{array}$ & & $23(17-32)$ & $10(7-11)$ & $1.8^{c}(1.7-2.5)$ & $5.1(4.8-5.9)$ \\
\hline $\begin{array}{l}\text { II }(n=6) \\
\text { Small reducing SHH }\end{array}$ & $18.5(8-29)$ & $35^{b}(25-49)$ & $16.5(5-25)$ & $1.8^{c}(1.0-2.5)$ & $4.9(4.1-6.3)$ \\
\hline $\begin{array}{l}\text { III }(n=18) \\
\text { Non-reducing SHH }\end{array}$ & $46^{a}(26-60)$ & $33^{b}(20-50)$ & $20^{b}(5-30)$ & $2.0^{c}(1.5-2.7)$ & $4.3(2.9-7.6)$ \\
\hline Group II and III $(n=24)$ & $38(8-60)$ & $33^{b}(20-50)$ & $20^{b}(5-30)$ & $2.0^{c}(1.0-2.7)$ & $4.4(2.9-7.6)$ \\
\hline Total $(n=29)$ & & $32.5(17-50)$ & $20(5-30)$ & $2.0^{c}(1.0-2.7)$ & $4.8(2.9-7.6)$ \\
\hline
\end{tabular}

SHH length - sliding hiatal hernia length - distance between the inferior margin of the lower oesophageal sphincter (the oesophagogastric junction point - "OGJ point") and crural diaphragm, MHW - maximum hiatus width - the greatest distance between the ridges of the crural diaphragm shafts, LOS length - distance between the superior and inferior margin of the lower oesophageal sphincter, OesoW oesophageal wall thickness within the oesophago-gastric junction, CardW-cardia wall thickness within the oesophago-gastric junction. aSignificant difference $(p<0.05)$ between group II and group III, " significant difference $(p<0.05)$ in the variable from group I in relation to the one from other groups, ${ }^{c} p<0.05$ OesoW vs. CardW.

Table 2. Sensitivity of the BSF, OGD, laparoscopic exploration during LARS and CT with Sengstaken-Blakemore tube probe as gold standard

\begin{tabular}{|lccccc|}
\hline Parameter & Positive & True positive & Negative & True negative & Sensitivity (\%) \\
OGD & $n$ & $n$ & $n$ & 3 & $71^{\mathrm{a}}$ \\
BSF & 19 & 17 & 10 & 3 & $54^{\mathrm{a}}$ \\
OGD and/or BSF & 13 & 13 & 16 & 3 & $79^{\mathrm{a}}$ \\
LARS & 21 & 19 & 8 & 5 & $75^{\mathrm{a}}$ \\
CTSBT & 18 & 18 & 11 & 5 & 100 \\
\hline
\end{tabular}

OGD - oesophagogastroduodenoscopy, BSF - barium swallow fluoroscopy, LARS - laparoscopic anti-reflux surgery, CTSBT - computed tomography scanning with Sengstaken-Blakemore tube. ${ }^{a} P<0.05$ between gold standard and each diagnostic method.

based on the abovementioned considerations, it might be impossible to differentiate the first group patients from the second by intraoperative laparoscopic findings. In which case, it might be appropriate to establish the CTSBT as the reference standard (Table 2).

The sensitivity was significantly higher in the CTSBT modality compared with each of the three other diagnostic tests, and even higher than in OGS and BSF together.

\section{Discussion}

This difference in the sensitivity between LARS and CTSBT modality is due to the fact that the presence of SHH during surgery was considered as credible if there was noted "a hernia sac and contents (gastric pouch) within it" (Figure 3 D) but not just "dimpling” anterior to the oesophagus. The last criteria can correspond not only to reducing $\mathrm{SHH}$ (Figure $2 \mathrm{D}$ ) but also to a dehiscence of the crural diaphragm with no existing SHH (Figure $1 \mathrm{D}$ ).

Although a contrast X-ray permits an efficient identification of the abnormality of the GOJ, it is less reliable for determination the exact position of the
GOJ. With due attention to the hiatus in intermediate phases of oral migration, the diaphragmatic sphincter action may be superimposed on the inferior margin of the lower oesophageal high-pressure zone [12] and may be measured in excess of the real length of the lower oesophageal sphincter.

In contrast to BSF (sensitivity 54\%), proximal migration of the GOJ or gastric cardia through the hiatus can be clearly visualised and measured by the CTSBT modality. It might also be helpful when the diagnosis is not clear or additional information is needed while planning a surgical intervention (namely such cases as presented here). Moreover, Koch et al. showed poor correlation between size of hiatal hernia seen on preoperative barium oesophagogram and intra-operatively measured hiatus area [13].

Computed tomography scanning with Sengstaken-Blakemore tube provocation is the most accurate method for the detailed description of hiatal insufficiency (hiatus widening), $\mathrm{SHH}$, and other types of hiatus hernia and has valuable advantages over other conventional diagnostic methods, despite its relatively high cost [6]. We believe that this "thirtysecond" method is more efficient and labor cost sav- 
ing in comparison with other conventional tests. The retroflexed imaging endoscopy was also less reliable (sensitivity 71\%) for identification of the SHH because of additional cofounding factors such as a lack of standardization in the conventional way of the hernia size measurement [10].

Our diagnostic modality is suitable for standardisation because the tube insertion technique, the degree of the balloon inflation, and even the degree of the tube traction can be described by a simple protocol. Although the last indicator ("traction strength") is interesting from a physiological rather than surgical point of view, as well as the differences in the LES length, which could possibly be explained by the fact that in patients without a hernia (group I), the traction of the SB tube caused a decrease of the LES length due to its compression between the upper edge of the gastric balloon and "not completely" compromised extrinsic sphincter - the crural diaphragm.

However, oesophagogastroduodenoscopy OGD has recently been playing a leading role in the diagnosis of erosive forms of GORD with typical symptoms and OGD, combined with a biopsy and subsequent histological examination of the specimens, and is regarded not only as the gold standard in the diagnosis of the erosive esophagitis, but also as the basic method for differential diagnosis of other diseases (complications), such as Barrett's disease and oesophageal adenocarcinoma [6].

Unfortunately, we have no capability to compare the developed method with high-resolution manometry, which was found to be highly sensitive and specific for hiatal hernia detection [14], with a sensitivity of $92 \%$ and specificity of $95 \%$, exceeding the sensitivity of endoscopy or radiography alone (both 73\%). However, despite the high sensitivity and specificity, high-resolution manometry does not provide a detailed description of the EGJ anatomy. Moreover, no significant differences were found by Khajanchee et al. [15] in the false negative results (sensitivity) between high-resolution manometry and endoscopy (47.62\% vs. $45.24 \%$ ) when intra-operative diagnosis of hiatal hernia was used as the gold standard.

Batirel et al. [16] estimated in 2009 and Koch et al. [17] confirmed in 2012 that a large hiatus area correlated with diminished LOS pressure and increased acid reflux in patients with GORD. Therefore, the preoperative measurement (scaling) of the hiatal hernia and oesophageal hiatus using CT is clinically important, especially when anti-reflux surgery is planned [18]. CT scan with Sengstaken-Blakemore tube provocation test as a preoperative diagnostic method can accurately confirm or exclude the diagnosis of any hiatal hernias, and can also reveal and describe subtle anatomical abnormalities in the OGJ region, such as dehiscence of diaphragm crura, thinning and shortening of the LES, the appearance of phreno-oesophageal membrane stretches, and displacement of the gastrooesophageal junction. In our study, other parameters such as the length of the oesophagus or presence of the A ring were measured; however, there was no significant difference between the groups and different diagnostic tests, which, however, does not exclude the possibility of diagnosing by CTSBT the indirect imaging signs of a short oesophagus, such as type I hiatal hernia or type III hiatal hernia or stricture more than $5 \mathrm{~cm}$ in size within the OGJ.

Considering the fact that the sliding hiatus hernia is not an "all or nothing" phenomenon [10], our method allows the determination of the degree of hiatal insufficiency and the inevitability of hernia development, which is an important piece of additional information for the surgeon when making a decision in favour of surgical treatment for GORD patients with incomplete symptom resolution on acid inhibition [19], as well as quality of life considerations, lifelong need for medication intake, expense of medications, etc. [20, 21].

\section{Conclusions}

The CTSBT study has been verified as an efficient and reliable diagnostic modality to confirm or rule out the diagnosis of $\mathrm{SHH}$ and other anatomical abnormalities in the OGJ region.

This method may be used to provide the surgeon with additional detailed information while making a decision about advisability of laparoscopic anti-reflux surgery for patients with incomplete symptom remission after appropriate medical therapy.

\section{Acknowledgments}

Authors would like to thank Dr Eugene Lifshits for his writing assistance in this manuscript.

\section{Conflict of interest}

The authors declare no conflict of interest.

\section{References}

1. Nawacki LG, Głuszek S, Kuder T. Benign diseases of the gastro-oesophageal junction. Medical Studies 2016; 32: 248-254.

2. Ott DJ, Gelfand DW, Chen YM, Wu WC, Munitz HA. Predictive relationship of hiatal hernia to reflux esophagitis. Gastrointest Radiol 1985; 10: 310-317.

3. Pouderoux P, Lin S, Kahrilas PJ. Timing, propagation, coordination, and effect of esophageal shortening during esophageal peristalsis. Gastroenterology 1997; 112: 1147-1154.

4. Shi G, Pandolfino JE, Joehl RJ, Brasseur JG, Kahrilas PJ. Distinct patterns of esophageal shortening during primary peristalsis, secondary peristalsis, and transient lower esophageal sphincter relaxations. Neurogastroenterol Mot 2002; 14: 505-512.

5. Pandolfino JE, Zhang Q, Ghosh S, Han A, Boniquit C, Kahrilas PJ. Transient lower esophageal sphincter relaxations and reflux: mechanistic analysis using concurrent 
fluoroscopy and high-resolution manometry. Gastroenterology 2006; 131: 1725-1733.

6. Kohn GP, Price RR, DeMeester SR, Zehetner J, Muensterer OJ, Awad Z, Mittal SK, Richardson WS, Stefanidis D, Fanelli RD. SAGES Guidelines for the management of hiatal hernia. Surg Endosc 2013; 27: 4409-4428.

7. Ott DJ, Gelfand DW, Wu WC, Castell DO. Esophagogastric region and its rings. Am J Roentgenol 1984; 142: 281-287.

8. Stilson WL, Sanders I, Gardiner GA, Gorman HC, Lodge DF. Hiatal hernia and gastroesophageal reflux. A clinicoradiological analysis of more than 1,000 cases. Radiology 1969; 93: 1323-1327.

9. Skinner DB. Hernias (hiatal, traumatic, and congenital). In: Bockus Gastroenterology. $4^{\text {th }}$ ed. Berk JE, Haubrich WS, Kalser MH, Roth JLA, Schaffner F (eds.). Saunders, Philadelphia, PA: 1985; 705-716.

10. Kahrilas PJ, Kim HC, Pandolfino JE. Approaches to the diagnosis and grading of hiatal hernia. Best Pract Research. Clin Gastroenterol 2008; 22: 601-616.

11. Hyun JJ, Bak YT. Clinical significance of hiatal hernia. Gut Liver 2011; 5: 267-277.

12. Mattioli S, D’Ovidio F, Di Simone MP, Bassi F, Brusori S, Pilotti V, Felice V, Ferruzzi L, Guernelli N. Clinical and surgical relevance of the progressive phases of intrathoracic migration of the gastroesophageal junction in gastroesophageal reflux disease. Thorac Cardiovasc Surg 1998; 116: 267-275

13. Koch O, Schurich M, Antoniou S, Spaun G, Kaindlstorfer A, Pointner R, Swanstrom L. Predictability of hiatal hernia/defect size: is there a correlation between pre- and intraoperative findings? Hernia 2014; 18: 883-888.

14. Weijenborg PW, van Hoeij FB, Smout AJ, Bredenoord AJ. Accuracy of hiatal hernia detection with esophageal high-resolution manometry. Neurogastroenterol Motil 2015; 27: 293-299.

15. Khajanchee YS, Cassera MA, Swanström LL, Dunst CM. Diagnosis of type-I hiatal hernia: a comparison of high-resolution manometry and endoscopy. Dis Esophagus 2013; 26: 1-6.

16. Batirel H, Uygur-Bayramicli O, Giral A, Ekici B, Bekiroglu N, Yildizeli B, Yüksel M. The size of the esophageal hiatus in gastroesophageal reflux pathophysiology: outcome of intraoperative measurements. J Gastrointest Surg 2009; 14: 38-44.

17. Koch O, Kaindlstorfer A, Antoniou S, Asche K, Granderath F, Pointner R. Influence of the esophageal hiatus size on the lower esophageal sphincter, on reflux activity and on symptomatology. Dis Esophagus 2012; 25: 201-208.

18. Ouyang W, Dass C, Zhao H, Kim C, Criner G; COPDGene investigators. Multiplanar MDCT measurement of esophageal hiatus surface area: association with hiatal hernia and GERD. Surg Endosc 2016; 30: 2465-2472.

19. Kahrilas PJ, Boeckxstaens G, Smout AJ. Management of the patient with incomplete response to PPI therapy. Best Pract Res Clin Gastroenterol 2013; 27: 401-414.

20. Stefanidis D, Hope WW, Kohn GP, Reardon PR, Richardson WS, Fanelli RD; SAGES Guidelines Committee. Guidelines for surgical treatment of gastroesophageal reflux disease. Surg Endosc 2010; 24: 2647-2669.

21. Jurkowska G, Świdnicka-Siergiejko A, Łagoda K, Sierżantowicz R, Dąbrowski A. Quality of life in patients with gastroesophageal reflux disease following pharmacothe- rapeutic, endoscopic, and surgical treatment. Medical Studies 2016; 32: 299-306.

\section{Address for correspondence:}

\section{Siarhei Panko}

Department of Emergency Medicine

Faculty of Health Sciences

Jan Kochanowski University of Humanities and Sciences

al. IX Wieków Kielc 19 A, 25-317 Kielce, Poland

Phone: +37 5291108819

E-mail: sppankam@gmail.com 